\title{
Sosialisasi dan Pelatihan Penyusunan Dokumen Mutu Lembaga Sertifikasi Profesi P1 bagi Calon Pengelola LSP P1 SMK Muhammadiyah Somagede, Banyumas
}

\author{
Socialization and Training of Quality Documents for P1 Profession Certification \\ Institution for Prospective Managers of LSP P1 SMK Muhammadiyah Somagede, \\ Banyumas
}

\author{
Mukhlis Prasetyo Aji $1^{*}$, Ermadi Satria Wijaya ${ }^{2}$ \\ 1,2Program Studi Teknik Informatika, Fakultas Teknik dan Sains \\ Universitas Muhammadiyah Purwokerto \\ Jl. Raya Dukuh Waluh, Kembaran 53182, Indonesia. \\ email: ${ }^{* 1}$ prasetyo-aji@ump.ac.id dan ²ermadi_satriya@yahoo.com
}

\begin{abstract}
ABSTRAK
Tidak bisa di pungkiri bahwa kualitas pekerja cukup rendah dimana tenaga kerja kita masih kalah bersaing dengan tenaga kerja yang berasal dari Malaysia, Singapura dan Thailand Apalagi untuk lulusan SMK, dibutuhkan sebuah pengakuan pentingnya keahlian bagi lulusan yaitu melalaui Sertifikasi Kompetensi. Karena sertifikasi kompetensi merupakan sebuah pengakuan terhadap tenaga kerja yang mempunyai keterampilan dan keemampuan yang mumpuni sesuai dengan standar kerja yang sudah ditetapkan. Sasaran sertifikasi kompetensi salah satunya dilakukan pada lulusan SMK karena lulusan SMK memang di persiapkan untuk langsung kerja. Untuk itulah Lembaga Sertifikasi Profesi (LSP) sangat diperlukan dilingkungan SMK dan siswa nantinya dapat di uji komptensinya. Dengan paparan di atas penting untuk di pahami terkait apa saja persiapan pendirian LSP yang salah satunya dokumen mutu.
\end{abstract}

Kata Kunci: BNSP, LSP, Manajemen Mutu, Sertifikasi.

\section{ABSTRACT}

It cannot be denied that the quality of workers is quite low where our workforce is still unable to compete with workers originating from Malaysia, Singapore and Thailand Especially for vocational graduates, it requires an acknowledgment of the importance of expertise for graduates through certification of competency. Because competency certification is an acknowledgment of the workforce who has qualified skills and abilities in accordance with the established work standards. One of the objectives of competency certification is for SMK graduates because vocational graduates are indeed prepared to work directly. For this reason, the Lembaga Sertifikasi Profesi (LSP) is very necessary in the vocational school environment and students can be tested in its competence. With the above explanation, it is important to understand the preparation of the establishment of LSP, one of which is quality documents.

Keywords: BNSP, LSP, Quality Management, Certification.

\section{Pendahuluan}

Perkembangan tenaga kerja di Indonesia kalah bersaing dengan tenaga kerja yang berasal dari luar negeri khsususnya negara ASEAN. Tentunya adanya perdagangan bebas antar negara-negara di kawasan ASEAN, atau yang biasa di sebut Masyarakat Ekonomi ASEAN (MEA). MEA sendiri adalah sistem perdagangan bebas antara negara-negara ASEAN dimana kawasan MEA mengharuskan membebaskan arus tenaga terampil. Oleh karena itu, sekarang banyak orang yang berlomba-lomba guna mendapatkan gelar akademik yang lebih tinggi (S1/S2/S3). Tetapi tidak semua lulusan SMK dapat melanjutkan 
pendidikan yang lebih tinggi (S1/S2/S3), oleh karena itu dibutuhkan sebuah pengakuan pentingnya keahlian bagi lulusan yang masih SMK yaitu melalui Sertifikasi Kompetensi. Karena sertifikasi kompetensi merupakan salah satu bentuk pengakuan terhadap tenaga kerja yang mempunyai keterampilan dan kemampuan yang sesuai dengan standar kerja yang sudah ditetapkan.

Di era milenial sekarang ini, sertifikasi sepertinya akan menjadi salah satu hal yang menunjang untuk tetap bertahan dalam pekerjaan. Dan yang sangat disayangkan, kesadaran masyarakat mengenai pentingnya sertifikasi kompetensi masih sangat kurang. Padahal, kesadaran itu yang harus kita bangun dari awal. Sertifikasi sebaiknya menjadi hal yang wajib dimiliki oleh tenaga kerja. Hal ini tentu berlaku tidak hanya untuk para pekerja formal saja, namun pekerja informal. Dengan sertifikasi kompetensi, para tenaga pekerja akan lebih tenang dalam bekerja dan juga diakui oleh negara atas keahlian yang dimiliki. Sehingga dengan memiliki sertifikasi kompetensi maka seseorang akan mendapatkan bukti pengakuan tertulis atas kompetensi yang dikuasai.Karena persaingan kerja antar profesi maupun lain profesi sangat ketat. maka, kalau kita tidak mampu atau kalah bersaing dalam hal kompetensi, bersiaplah untuk tergusur dari persaingan.

Melalui Amanat Undang-Undang Nomor 13 Tahun 2013 tentang Ketenagakerjaan yang pembentukannya berdasarkan Peraturan Pemerintah Nomor 23 tahun 2004 tentang Badan Nasional Sertifikasi Profesi, Negara Indonesia telah membentuk Badan Nasional Sertifikasi Profesi (BNSP). BNSP merupakan badan independen yang bertanggung jawab kepada Presiden yang memiliki kewenangan sebagai otoritas sertifikasi personil dan bertugas melaksanakan sertifikasi kompetensi profesi bagi tenaga kerja (Hapsari M,2016). Sehingga diharapkan dapat meningkatkan kemampuan kita dan mempersiapkan diri untuk menghadapi semua persaingan. Untuk sasaran sertifikasi kompetensi salah satunya dilakukan pada lulusan SMK karena lulusan SMK memang di persiapkan untuk langsung kerja.

Untuk itulah Lembaga Sertifikasi Profesi (LSP) sangat diperlukan dilingkungan SMK dan siswa nantinya dapat di uji kompetensinya. Untuk itu melalaui pelatihan ini diharapkan dapat berdirinya Lembaga Sertifikasi Profesi di SMK Muhammadiyah Somagede, Banyumas. Salah satu syarat berdirinya LSP yaitu mempunyai dokumen mutu.

\section{Metode}

Metode Dalam pelaksanaan kegiatan pelatihan manajemen mutu LSP berdasarkan permasalahan dan manfaat yang akan di peroleh antara lain berupa sosilisasi dokumen mutu LSP. Pelatihan ini menggunakan metode ceramah, demonstrasi, tanya jawab (diskusi), dan praktik langsung menggunakan perangkat komputer (Mustafidah,H.,2018). Kegiatan pelatihan penyusunan dokumen mutu LSP dilakukan di SMK Muhammadiyah Somagede,Banyumas. Pelatihan ini rencananya akan di ikuti 21 peserta dari pihak mitra.

Adapaun kegiatan pelatihan ini dilaksanakan dalam 5 tahap :

1. Tahap pertama merupakan persiapan materi pelatihan penyusunan dokumen mutu.

2. Pada tahap ini dilaksanakan proses transfer pengetahuan dari instruktur kepada peserta (mitra kegiatan ) berupa :

a. Materi tentang dokumen yang harus di siapkan pendirian LSP khususnya dokumen mutu.

b. Praktek tentang penyusunan dokumen mutu.

c. Praktek tentang pembuatan SOP.

3. Tahap Evaluasi Pelatihan

4. Pada tahap ini dilakukan evaluasi terkait hasil dari pelatihan dokumen atau draf manual mutu dan SOP yang telah dibuat.

5. Tahap ini merupakan tahap evaluasi terkait dokumen yang telah dibuat. 


\section{Hasil dan Pembahasan}

Pelaksanaan penyusunan dokumen mutu LSP dilakukan di SMK Muhammadiyah Somagede, Banyumas. Pelatihan ini di ikuti Guru SMK Muhammadiyah Somagede,Banyumas yang berjumlah 21 peserta terdiri dari Kepala Sekolah dan Guru bidang Studi. Pelatihan ini memberikan gambaran mengenai pentingnya LSP, dokumen mutu dan Standar Operasional Prosedur (SOP) LSP. Hasil dari pelatihan ini ditinjau dari beberapa aspek antara lain:

\section{Aspek Pengetahuan}

Kompetensi merupakan suatu karakteristik yang mendasar dari seseorang individu, yaitu penyebab yang terkait dengan acuan kriteria tentang kinerja yang efektif " $A$ competency is an underlying characteristic of an individual that is causally related to criterion-referenced effective and/or superior performance in a job or situation" (Spencer \& Spencer, 1993:9). Secara lebih rinci, Spencer dan Spencer (2007:84) mengemukakan bahwa kompetensi menunjukkan karakteristik yang mendasari perilaku yang menggambarkan motif, karakteristik pribadi (ciri khas), konsep diri, nilai-nilai, pengetahuan atau keahlian yang dibawa seseorang yang berkinerja unggul (superior performer) di tempat kerja.

Dengan kata lain kompetensi adalah karakteristik seseorang yang berkaitan dengan kinerja efektif dan atau unggul dalam situasi pekerjaan tertentu. Kompetensi dikatakan sebagai karakteristik dasar (underlying characteristic) karena karakteristik individu merupakan bagian yang mendalam dan melekat pada kepribadian seseorang yang dapat dipergunakan untuk memprediksi berbagai situasi pekerjaan tertentu. Kemudian dikatakan berkaitan antara perilaku dan kinerja karena kompetensi menyebabkan atau dapat memprediksi perilaku dan kinerja (Yamu'alim, 2016).

Untuk itu perlu adanya cara menggali kompetensi seseorang agar pengetahuan atau keahlian yang dimilikinya sesuai dengan kebutuhan tempat kerja. Di Indonesia sudah ditetapkan Standar Kompetensi Kerja Nasional Indonesia (SKKNI), merupakan acuan yang menjadi standar dalam hubungannya dengan kemampuan kerja yang meliputi aspek keterampilan, pengetahuan dan sikap kerja yang sesuai dengan pelaksanaan tugasnya. Hal ini sesuai dengan persyaratan dari pekerjaan yang sudah ditetapkan dimana semua standar atau ketentuan dalam SKKNI sesuai dengan ketentuan dalam peraturan perundang-undangan yang berlaku.

Melalui Peraturan Pemerintah No. 23 Tahun 2004 maka dibentuklah Badan Nasional Sertifikasi Profesi (BNSP) yang mempunyai tugas melaksanakan sertifikasi kompetensi kerja. Dalam melakukan tugas-tugasnya BNSP dibantu Lembaga Sertifikasi Profesi (LSP), sehingga dalam pelaksanaan uji komptensi dilakukan oleh LSP. Untuk menyiapkan atau mendirikan Lembaga Sertifikasi Profesi ada beberapa syarat yang harus di penuhi salah satunya adalah sistem manajemen mutu. Sistem Manajemen Mutu adalah kumpulan proses, dokumen, sumberdaya dan sistem pemantuan yang mengarahkan pekerjaan atau misi suatu organisasi berkenaan dengan mutu produk dan jasa. Dokumen yang diperlukan sistem manajemen mutu sesuai dengan Peraturan BNSP nomor 201 dan 202 antara lain : Panduan Mutu, SOP(Prosedur dan Instruksi kerja), Formulir dan dokumen pendukung. Berdasarkan wawancara, tanya jawab dan pengamatan langsung selama kegiatan berlangsung, kegiatan pengabdian masyarakat ini memberikan hasil sebagai berikut:

1. Meningkatnya pengetahuan dan pemahaman tentang Standar Kompetensi Kerja Nasional Indonesia.

2. Meningkatnya pengetahuan tentang penyusunan dokumen pendirian LSP salah satunya dokumen mutu.

3. Meningkatnya pengetahuan tentang membuat Standar Operasional Prosedur. 


\section{Aspek Ketrampilan}

Dalam melakukan sistem manajemen mutu pada LSP salah satu yang harus dilengkapi adalah panduan mutu dan Standar Opersional Prosedur hal ini sesuai Peraturan BNSP nomor 201 dan 202. Dokumen mutu merupakan pusat pengendali yang menetapkan kebijakan dan prinsip - prinsip dasar fungsi LSP. Dan Dokumen kerja atau SOP merupakan dokumen yang menerangkan kebenaran pengoperasian LSP untuk digunakan oleh manajemen dan staf. Panduan mutu yang harus di buat sesuai dengan format yang sudah ditetapkan BNSP terdiri dari 2 hal yaitu :

1. Halaman depan

Halaman depan merupakan cover dari dokumen panduan mutu yang terdiri dari halaman judul, validasi, kata pengantar,amandemen dan daftar isi.

2. Isi

Bagian ini merupakan isi dari dokumen panduan mutu yang terdiri dari Profil LSP, istilah dan definisi, distribusi dokumen, persyaratan untuk LSP, persyaratan struktur organisasi, persyaratan sumber daya, persyaratan sumber daya,peryaratan rekaman dan informasi,skema sertifikasi,persyaratan proses sertifikasi dan persyaratan sistem manajemen

\section{Aspek Produk}

Berdasarkan kegiatan pelatihan pembuatan dokumen panduan mutu dan standar operasional prosedur LSP yang telah dilakukan dapat dihasilkan berupa modul pelatihan, draf panduan mutu dan draf standar operasional prosedur.

\section{Kesimpulan}

Dalam era milenial kebutuhan akan sertifikasi kompetensi sangat diperlukan dan yang sangat di sayangkan kesadaran akan sertifikasi dalam masyarakat mengenai pentingnya sertifikasi kompetensi masih sangat kurang, apalagi lulusan Sekolah Menengah Kejuruan (SMK). Banyak Sekolah Menengah Kejuruan (SMK) belum menerapkan sertifkasi kompetensi sehingga lulusannya kurang bersaing. Untuk melakukan sertifikasi kompetensi harus ada Lembaga Sertifikasi Profesi (LSP) sebagai lembaga yang melakukan uji kompetensi. Banyak SMK yang belum mempunyai LSP khususnya di Lembaga Pendidikan Muhammadiyah, untuk itu diperlukan sosialisasi dan pelatihan terkait sertifikasi dengan metode ceramah, demonstrasi, tanya jawab (diskusi), dan praktik langsung dalam mempersiapkan LSP. Salah satu materi yang diberikan adalah Standar Kompetensi Kerja Nasional (SKKNI), uji sertifikasi kompetensi dan keterampilan pembuatan dokumen mutu dan standar opersional prosedur (SOP) uji kompetensi. Melalui pelatihan ini pemahaman guru SMK terkait prosedur dan dokumen uji kompetensi semakin meningkat sehingga dalam pendirian LSP nanti diharapkan dapat meningkatkan kualitas atau kompetensi peserta didiknya.

\section{UCAPAN TERIMA KASIH}

Pengabdian ini kami ucapkan terima kasih kepada Lembaga Penelitian dan Pengabdian Masyarakat, Prodi Teknik Informatika, Lembaga Sertifikasi Profesi Universitas Muhamamdiyah Purwokerto atas Kerjasama terkait pendanaan,materi dan sumberdaya lainnya. Tak lupa kami juga ucapkan terima kasih kepada mitra dari SMK Muhammadiyah Somagede, Banyumas. 


\section{DAFTAR PUSTAKA}

Hapsari, Melati Indri.(2016). Pengkajian Program Kursus dan Pelatihan Terkait dengan Jenis Keterampilan ,Sertifikasi dan Penempatan Lulusan. Journal of Nonformal Education, 2(1). https://doi.org/10.15294/jne.v2i1.5314

Mustafidah, H., Harjono, H., \& Purwo Wicaksono, A. (2018). Peningkatan Kemampuan Menganalisis Butir Soal Tes bagi Guru-guru MGMP IPS Menggunakan Program QUEST. JPPM (Jurnal Pengabdian Dan Pemberdayaan Masyarakat), 2(1), 47. https://doi.org/10.30595/jppm.v2i1.1430

Spencer, Lyle M., \& Spencer Signe M.(1993). Competence at Work, Models for Superior Performance. John Wiley \& Sons, Inc. Toronto.Canada.

Yamu'alim. (2015). Sertifikat Kompetensi Sebagai Standar Kompetensi Kerja, Forum Manajemen, Vol. 06 No. 1. 